岡山医誌（1997） 109，1 6

\title{
新生児期発症のてんかんにおける脳形成障害 および心身障害についての検討
}

岡山大学医学部小児神経科（現・吉備国際大学保健科学部 $*$ )

真田敏・岡鍈次 - 大田原俊輔*

岡山大学医学部放射線科

河原 道子・栄 勝美・平木 祥夫

(平成 8 年12月 4 日受稿)

Key words：新生児期, 局在関連性てんかん, 心身障害, 脳形成障害, MR スペクトロスコピー

\section{緒}

新生児期は脳内の髄鞘化やシナプス形成が末 だ進んでいないことなどから，痙摹準備性が低 く，てんかんの発症は稀とされている。

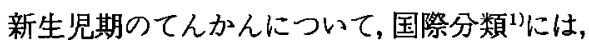
特発性全般てんかんとして良性家族性新生児け いれんおよび良性新生児けいれん，症候性全般 てんかんとして早期ミオクロニー脳症 (early myoclonic encephalopathy：EME)，および大 田原症候群，さらに未決定てんかんとして新生 児発作がとりあげられている。これらの内, EME， 大田原症候群㧍よび良性家族性新生児けいれん

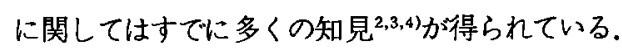
しかし，その他のてんかん病型の分布や原因に ついては不明の点が多い。そこで新生児期に発 症するてんかんについて, 脳形成障害や心身障 害の合併, および，てんかんの病像の変容など 臨床的特徵を明らかにし, 同時に脳形成障害部 位のMRスペクトロスコピー所見についても明 らかにしたいと考えた。

\section{対象と方法}

1982年から1994年までの 12 年間に岡山大学小 児神経科に入院したてんかん770症例について調
查し, 生後 4 週未満の発症が推測されるてんか ん症例を以下の基準で選別した。

1）新生児期の一過性けいれん発作は除外する.

2 ) 周生期脳障害や新生児期の急性代謝異常に 伴う急性痓䇣は除外する。

3）新生児期の発作に連続して，その後のてん かん発作を認める。

4) 生後 3 カ月未満の早期乳児期に，てんかん 性脳波異常を確認。

以上の基準で選別された症例は21例でその内 訳を表 1 に示した。これらの症例の内, 症候性 局在関連性てんかん6例と未決定てんかん 1 例 の計 7 例について詳細な検討を行った。

さらに MRI 所見から hemimegalencephaly と考えられた 1 例と, heterotopic gray matter

表 1 新生児期に発症したてんかん

\begin{tabular}{|c|c|c|}
\hline \multicolumn{3}{|l|}{ 全般てんかん } \\
\hline 特発性 & 良性家族性新生児けいれん & 1 \\
\hline \multirow[t]{2}{*}{ 症侯性 } & 早期ミオクロニー船症 (EME) & 9 \\
\hline & 大田原症侯群 & 4 \\
\hline \multicolumn{3}{|c|}{ 局在関連性てんかん } \\
\hline \multirow{2}{*}{$\begin{array}{c}\text { 症候性 } \\
\text { 未決定てんか人 }\end{array}$} & & 6 \\
\hline & & 1 \\
\hline
\end{tabular}


と考えられた 1例について, ${ }^{1} \mathrm{H}-\mathrm{MR}$ スペクトロ スコピーによる検討を行った，方法は Siemens 社製, Magnetom H15（1.5 tesla）を用い, STEAM 法で TR $1500 \mathrm{msec}$, TE $270 \mathrm{msec}$, aquisition 320回の条件で，関心領域は2.5× $2.5 \times 2.5 \mathrm{~cm}^{2} \sim 3 \times 3 \times 3 \mathrm{~cm}^{2}$ の大きさに設定し, 病変部位および反対側の対称部位の測定を行い 比較㭘討した. N-acetylaspartate (NAA；2.0 $\mathrm{ppm})$, creatin $(\mathrm{Cr} ; 3.0 \mathrm{ppm})$, および choline (Ch：3.2 ppm)のピーク面積をもとめ,ついで 面積比 $\mathrm{NAA} / \mathrm{Cr}$ および $\mathrm{Ch} / \mathrm{Cr}$ を算出しこれら を検討した。

成

績

1. 発作の初発日齢および発作型

症候性局在関連性てんかんと末決定てんかん の計 7 症例の発作の初発日齢は生後 2 日以内 2 例，14日以内 3 例，28日以内 2 例であった，新 生児期にみられた発作としては, 全般強直発作 1 例，部分発作を示寸強直発作 5 例，間代性部 分発作 1 例で，部分発作を示す強直発作では 2 例において口部自動症を伴っていた。これらの 症状には急性痓省における症状に比し特に差は みられなかったが, 微細発作のみのことはなく， 痙戀の樣相が明白であった。

\section{2. 生下時体重および在胎週数}

7 症例中 6 例は成熟児で，早期産低出生体重 児は 1 例（35週，2360g）のみであった。

3．痤戀またはてんかんの家族歷

第 П度近親以内に痤變の家族歴を認めたもの は 7 例中 2 例であった。

\section{4.てんかんの病像の変容}

1 年 5 力月から 10 年 (平均 5 年 9 力月) の予 後追跡の結果, 図 1 に示すように発作消失は 7 例中 2 例にみられた。 5 例は難治性で，内 4 例 は前頭葉てんかん，残り1例はsevere epilepsy with multiple independent spike foci (MISF) ${ }^{\text {s) }}$ であった。 また 7 例中 3 例は乳児期から幼児期 初期にWest 症候群に発展し，内 1 例が発作消 失, 1 例が前頭葉てんかん, 残り 1 例が MISF に変容した.West 症候群を呈した時期の 3 症例 の特徴を表 2 に示した.West 症候群として早発 が 2 例，遅発は 1 例であった。2例において部
分発作を伴っており，そのうち 1 例では, 部分 発作がシリーズ性強直発作に先行するという特 異な発作型を示した。

\section{5 . 心身障害の合併}

7 症例にお汁る 1 年 5 力月から 10 年，平均 5 年 9 力月の予後追跡の結果, 精神・運動発達の 予後は, 重度精神 - 運動発達障害 4 例, 中等度 精神・運動発達障害 1 例, 軽度精神・運動発達 障害 1 例，境界域 1 例で，7例中 6 例 (85.7\%) に軽度から重度の精神・運動発達障害を認めた。

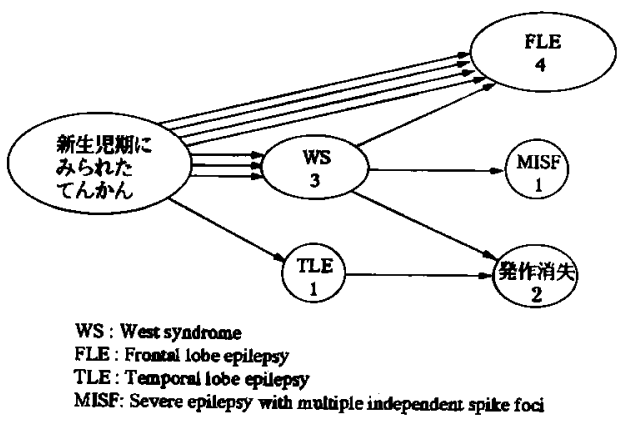

図 1 てんかんの病像の変化

表 2 West 症候群を呈した 3 症例の特幑

\begin{tabular}{lccc}
\hline \multicolumn{1}{c}{ 症 例 } & T. Y. & K. A. & O. M. \\
\hline 出現月齢 & 3 & 3 & 24 \\
\hline 部分発作 & $+*$ & + & - \\
単発発作 & - & + & + \\
睡眠時発作 & - & - & + \\
\hline Hypsarythmia & & & + \\
asymmetry & + & & + \\
periodic & \multicolumn{3}{c}{+} \\
modified & \multicolumn{3}{c}{+} \\
\hline *: 部分発作がシリーズ発作に先行する
\end{tabular}

表 3 画像所見

\begin{tabular}{ll}
\hline 一側半球肥大, 脳满不明瞭 & 1 \\
(Hemimegalencephaly) & \\
T 2 強調画像で左前頭部低信号域 & 2 \\
(Heterotopic gray matter) & \\
両側脳室拡大 & 1 \\
前頭部萎樎 & 2 \\
特記すべき所見なし & 1 \\
\hline
\end{tabular}


一方, 症候性全般てんかんの EME 9 例と大 田原症候群 4 例の計13例全例に, 重度精神・運 動発達障害を認めた。

6 . 画像所見

MRIによる画像所見を表 $3 に$ 示した.一側半 球肥大と脳淦不明瞭を示した 1 例は, MRI 所見 から hemimegalencephaly と考えられ，前頭葉 皮質下に $\mathrm{T}_{2}$ 強調像で低信号域を示した 2 例は， heterotopic gray matter と考えられた。 その 他, 両側側脳室拡大 1 例, 前頭部萎縮 2 例を認 め，7例中 6 例 $(85.7 \%)$ に画像所見上の異常 を認め, 多くの症例で脳形成障害が疑われた。

7. ${ }^{1} \mathrm{H}-\mathrm{MR}$ スペクトロスコピー所見

図 2 に hemimegalencephalyと考えられる1 例（1歳8カ月）における， ${ }^{1} \mathrm{H}-\mathrm{MR}$ スペクトロ スコピー所見を示した. $\mathrm{NAA} / \mathrm{Cr}$ 比は病変側の 傍側脳室, 基底核および梁部白質から灰白質に かけての $3 \times 3 \times 3 \mathrm{~cm}^{3} の$ 関心領域において 1.30 で, 反对側の同一の大きさの関心領域における 同比2.03に比し低值を示した. 一方, $\mathrm{Ch} / \mathrm{Cr}$ 比 は病変側において1.62で, 反対側の同比 $1.83 に$
比し軽度低值を示した.

図 3 に heterotopic gray matter と考えられ る1例（生後8力月）における ${ }^{1} \mathrm{H}-\mathrm{MR}$ スペク トロスコピー所見を示した. NAA/Cr 比は病変 側を含む $2.5 \times 2.5 \times 2.5 \mathrm{~cm}^{3}$ の関心領域において $1.41 て ゙$, 反対側の同比1.89に比し低值を示した. 一方, $\mathrm{Ch} / \mathrm{Cr}$ 比は病変側において2.13で, 反対 側の同比1.82に比し軽度高值を示した.

考察

新生児期に発症するてんかんは稀であるが， そのてんかん病型は必ずしも単純ではない。そ の原因として素因, 代謝異常, 脳形成障害など が推測されている。すなわち，良性家族性新生 児けいれんにおいては素因, EMEにおいては代 謝異常, 大田原症候群においては脳形成障害が 重要な要因とみなされている. 本研究で, 新生 児期に発症し特殊なてんかん症候群に属さない てんかんについて倹討した結果, 脳形成障害を 示した症例が多く認められ，推定原因として重 要と考えられた。

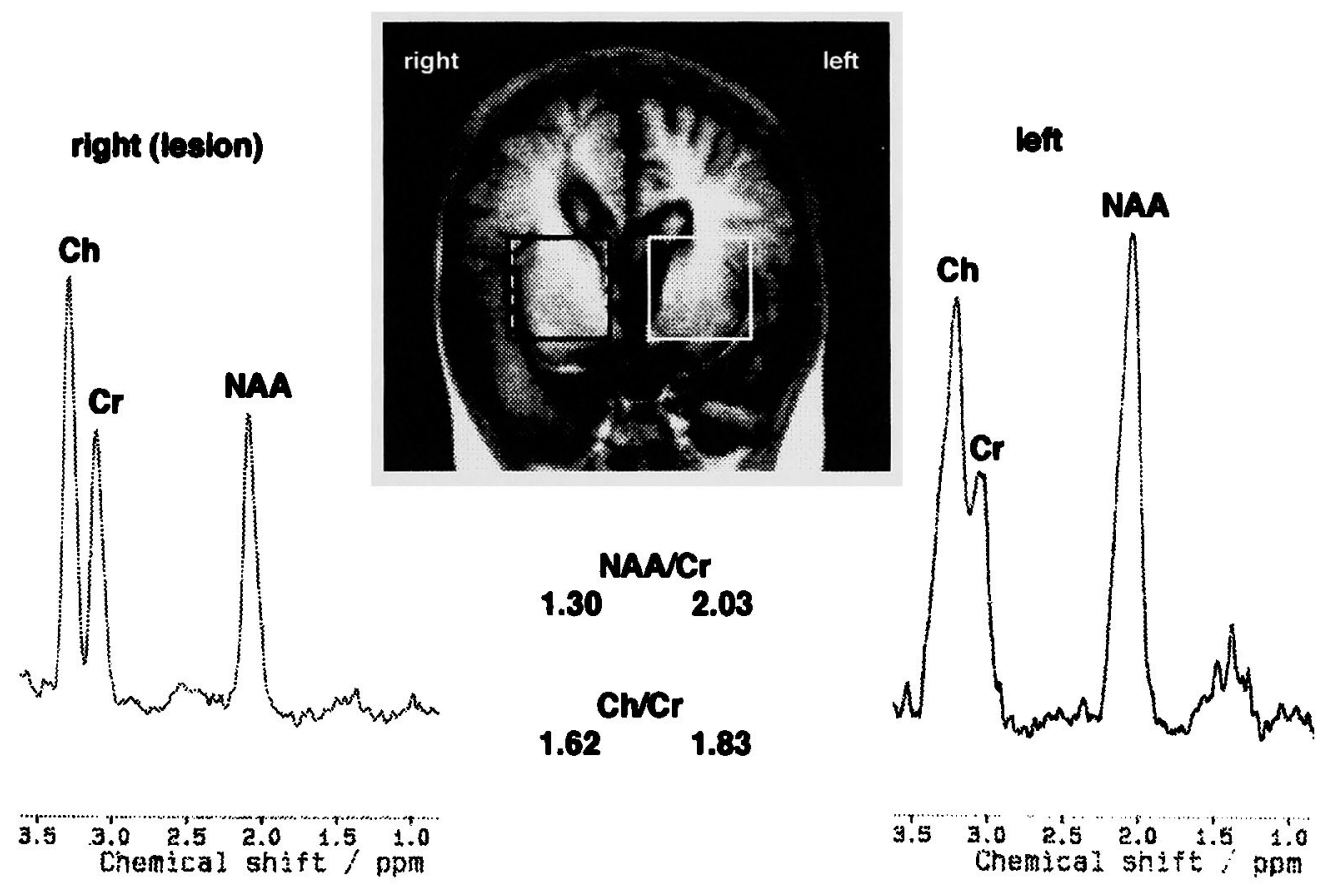

困 2 Hemimegalencephaly における ${ }^{1} \mathrm{H}-\mathrm{MR}$ スペクトロスコピー

黒四角が病変側における関心領域, 白四角が反対側における関心領域を示す. 


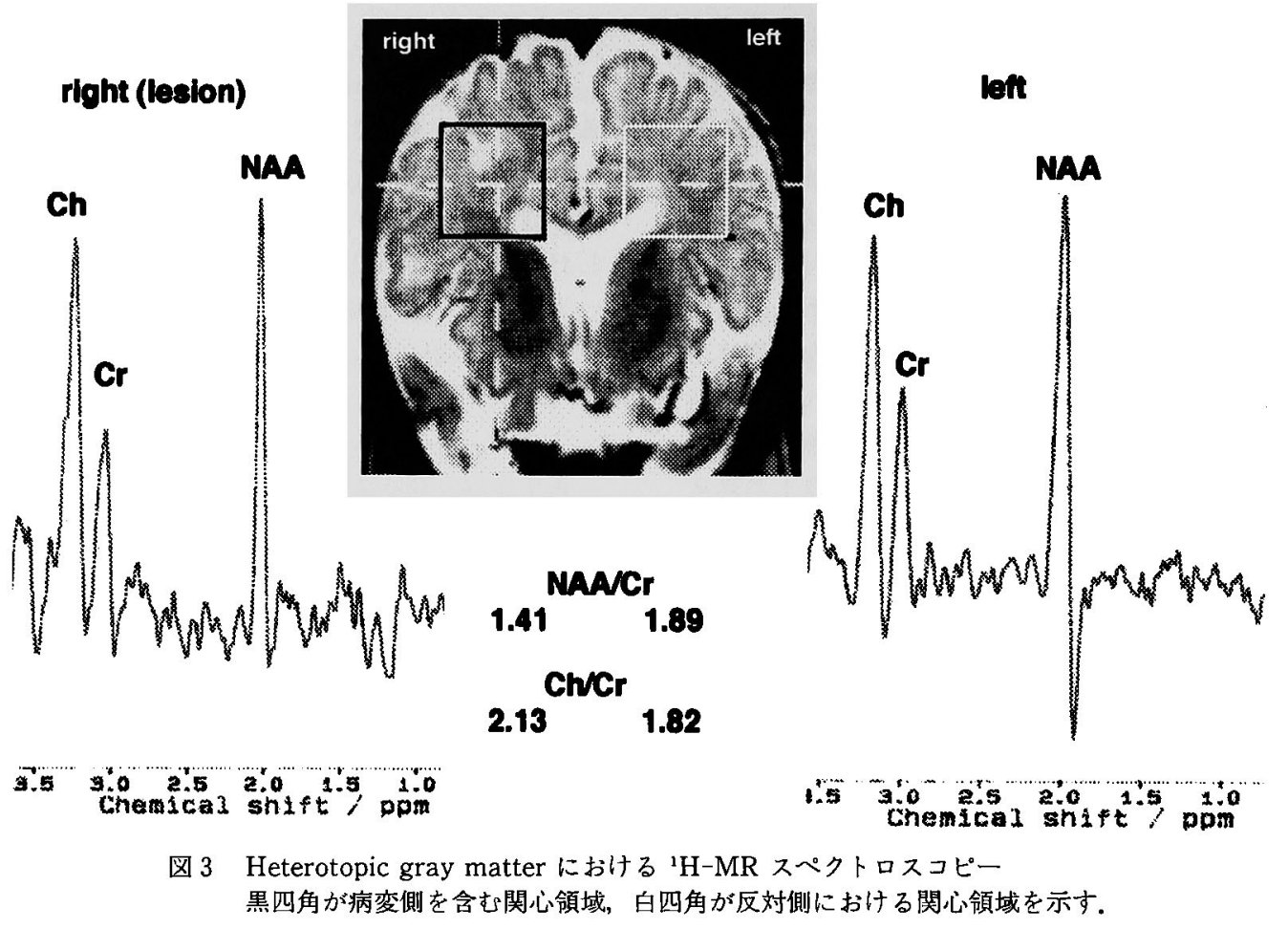

心身障害の合併率に関し, 大田原ら ${ }^{6}$ は15歳以 下のてんかん患者1072例の調査で難治てんかん の41.5\%に精神遅滞を，29.3\%に運動障害を認 め，一方発作抑制群では各々 $5.5 \%$ よび $3.5 \%$ と低率であることを報告している．本成績の症 候性局在関連性てんかんおよび未決定てんかん の 7 症例に扔ける, 精神・運動発達障害合併率 は85.7\%で極めて高率であり，基盤にある脳形 成障害との関連が推測された。

最近, ニューロン遊走障害による脳形成障害 を基盤にする難治てんかんが注目されているが文， それらのてんかん発症の時期か新生児期である ことは稀である。従って，新生児期にてんかん が発症するためには，何らかの加重要因が必要 であるのかもしれない。松田 ${ }^{8,99}$ は，出生前要因 によるてんかんの検討を行い，新生児けいれん を認めた症例には周生期障害も伴っていたこと を指摘しているが，これは本研究の対象には該 当しなかった。

さらに、ニューロン遊走障害に㧍ける MRス ペクトロスコピーに関しての報告は未だ苏めて そしいが, Hanefeld ら゚はは最近 hemimegalence- phaly の10歳および13歳の 2 症例において, 障 害側での $\mathrm{NAA} / \mathrm{Cr}$ 比の低下と $\mathrm{Ch} / \mathrm{Cr}$ 比の增加 を報告している，NAA は神経細胞に特異的に 存在するアミノ酸であり，神経細胞の機能評価 に有用 ${ }^{11}$ とされており, 本研究の 2 症例や Hanefeld らの 2 症例における NAA/Cr 比低下 はこれらの障害部位における神経細胞の減少ま たは機能低下を反映したものと考えられる。ま た，Ch はmyelineのリン脂質のturn over に関 連していることから， myelination および demyelination を反映すると考えられている ${ }^{12)}$ が, $\mathrm{Ch} / \mathrm{Cr}$ 比の成績は本研究と Hanefeld らの 報告では一致して扔らず，今後対象の年齢など も考慮した㭘討を要するものと思われる。

経過型からみて興味深いことは，3例におい て生後3カ月および 2 歳において, West 症候群 の時期がみられたことである．さらにその後， 局在関連てんかんやMISF を呈したが，このよ うな变容は Aicardi 症候群に認められることが あり ${ }^{13)}$, 脳形成障害を基盤にする難治てんかんの 経過型の一つと考えられる。 


\section{結 論}

新生児期に発症するてんかんのうち，特殊な 症候群に属さないてんかんについて検討した。 症候性局在関連てんかんの前頭葉てんかん，側

頭葉てんかんおよび MISF を認め，高率に心身 障害の合併がみられた。その推定原因としては 脳形成障害が重要とみなされた。しかし，新生 児期に早発する要因に関してはなお未解明であ る.

\section{文献}

1) Commission on Classification and Terminology of the International Leage Against Epilepsy : Proposal for revised classification of epilepsies and epileptic syndromes. Epilepsia (1989) 30, 389-399.

2) Aicardi J : Early myoclonic encephalopathy ; in Epileptic Syndromes in Infancy, Childhood and Adolescence, Roger J, Dravet C, Bureau M, Dreifuss FE and Wolf P eds, John Libbey, London, (1985) pp 12-22.

3) Ohtahara S, Ohtsuka Y, Yamatogi Y and Oka E : The early-infantile epileptic encephalopathy with suppression-burst : Brain Dev (1987) 9, 371-376.

4) Plouin $P$ : Benign Neonatal Convulsions ; in Epileptic Syndromes in Infancy, Childhood and Adolescence, Roger J, Dravet C, Bureau M, Dreifuss FE and Wolf P eds, John Libbey, London, (1985) pp 2 $-11$.

5) 水川美智子：Severe epilepsy with multiple indendent spike foci に関する研究。てんかん研究 (1992) 10, $78-87$.

6）大田原俊輔，大塚頌子，荻野竜也，村上啺子、吉永治美，御牧信義，小林勝弘：小児期のてんかんに関する 検討. 厚生省神経疾患委託研究費，難治てんかんの成因と治療に関する研究，昭和60年度報告書 (1985) pp $53-59$.

7) Sperner J, Bittner R, Scheffner D and Felix R : Migration disorders and epilepsy ; in Proceedings of the International Symposium "New Trends in Pediatric Epileptology", Ohtahara S and Roger J eds, Okayama (1990) pp 72-79.

8）松田 都：小児てんかんに扔ける出生前要因の検討：第 1 編：出生前要因に基づくてんかんの臨床的研究. 腷と発達（1985） 17，231-237。

9）松田 都：小児てんかんにおける出生前要因の㭘討；第 2 編：出生前要因に基づくてんかんの脳波に関する 研究. 脳と発達 (1985) 17, 238-244.

10) Hanefeld F, Kruse B, Holzbach U, Christen HJ, Merboldt KD, Hänicke W and Frahm J : Hemimegalencephaly : Localized proton magnetic resonance spectroscopy in vivo. Epilepsia (1995) 36, $1215-1224$.

11）成瀬昭二：磁気共鳴法による脳の代謝機能画像 一小児神経疾患への適用を中心に一，（1994）26，S82.

12) van der Knaap MS, van der Grond J, Luyten PR, den Hollander JA, Nauta JJP and Valk J : ${ }^{1} \mathrm{H}$ and ${ }^{31} \mathrm{P}$ magnetic resonance spectroscopy of the brain in degenerative cerebral disorders. Ann Neurol (1992) 31, 202-211.

13) Ohtsuka $Y$, Oka E, Terasaki $T$ and Ohtahara $S$ : Aicardi syndrome : A longitudinal clinical and electroencephalographic study. Epilepsia (1993) 34, 627-634. 


\section{Cerebral dysgenesis and psychomotor retardation}

in neonatal epilepsy

Satoshi Sanada, Eiji OKa and Shunsuke Ohtahara*

Department of Child Neurology,

Okayama University Medical School,

(Kibi International University Health Sciences School*)

Michiko Kawahara, Katsuyoshi SaKae and Yoshio Hiraki

Department of Radiology,

Okayama University Medical School,

Okayama 700, Japan

A clinical and neuroradiological study was carried out to clarify the relationship among cerebral dysgenesis, psychomotor retardation and neonatal epilepsy. Twenty-one cases with epilepsy developed within four weeks after birth were selected among 770 in-patients with childhood epilepsy. They consisted of one benign familial neonatal convulsion, nine of early myoclonic encephalopathy, four of Ohtahara syndrome, six of symptomatic localizationrelated epilepsy, and one of undetermined epilepsy. Seven cases with non specific types of epilepsies were investigated in detail. They developed into four of frontal lobe epilepsy, one of temporal lobe epilepsy and one severe epilepsy with multiple independent spike foci. Psychomotor retardation was observed in six of seven cases, and cerebral dysgenesis was considered to be important as an etiological factor. Proton MR spectroscopy revealed the decrease in the ratio of $\mathrm{N}$-acetylaspartate/choline in the area with heterotopic gray matter and in the side of hemimegalencephaly, contrasted with a contralateral area without lesions. These findings can be inferred to reflect the decreased numbers of neuronal cell population or reduced metabolism in the lesions. 